Article

\title{
Disentangling Mining and Migratory Routes in West Africa: Decisions to Move in Migranticised Settings
}

\author{
Matthieu Bolay \\ Centre on Conflict, Development and Peacebuilding, Graduate Institute of International and Development Studies, \\ 1202 Geneva, Switzerland; E-Mail: matthieu.bolay@graduateinstitute.ch
}

Submitted: 2 October 2020 | Accepted: 23 October 2020 | Published: 25 March 2021

\begin{abstract}
This article scrutinizes the trajectories of African men whose cross-border movements intersect two types of mobility routes: mining and migration routes. Drawing on field research in Mali and Guinea, as well as phone interviews with male miners/migrants in North Africa and Europe, this article provides a case to empirically question some of the premises in the approach to migration decision-making by giving a voice to African men moving across borders who do not necessarily identify as (prospective) 'migrants.' Building upon International Organization for Migration data and secondary sources, this article starts by sketching where migration and mining routes overlap. It then examines, in detail, the mobility trajectories of men who were sometimes considered migrants and other times miners in order to identify how these different routes relate to one another. While overseas migration is certainly not a common project for itinerant miners, the gold mines constitute a transnational space that fosters the expansion of movements across the continent, including outside the field of mining. Rather than encouraging overseas migration, gold mines appear to be more of a safety net, not only for seasonal farmers or young people in search of money and adventure, but also, increasingly, for people who are confronted with Europe's intra-African deportation regime.
\end{abstract}

\section{Keywords}

artisanal and small-scale mining; border regime; Guinea; Mali; migration; mobility; North Africa; West Africa

\section{Issue}

This article is part of the issue "Decision-Making under Uncertainty: African Migrants in the Spotlight" edited by Didier Ruedin (University of the Witwatersrand, South Africa / University of Neuchâtel, Switzerland).

(C) 2021 by the author; licensee Cogitatio (Lisbon, Portugal). This article is licensed under a Creative Commons Attribution 4.0 International License (CC BY).

\section{Introduction}

West Africa is considered to have the most mobile population in the world, with intra-regional mobility accounting for $70 \%$ of all cross-border movements according to the International Organization for Migration (IOM). Intense mobility in West Africa has deep historical roots (De Bruijn, van Dijk, \& Foeken, 2001) involving interwoven migration cultures of kinship and ethnicized labour specialization, as well as mobile livelihood and education strategies (Hahn \& Klute, 2007). As Bilger and Kraler (2005, p. 10) argue, mobility, rather than sedentariness, is considered the norm in the region. This article jointly examines two important forms of movement that are part of this intense West African mobility, but which have so far been analysed separately: labour mobility in arti- sanal gold mines and migration mobility to North Africa or Europe. The article proceeds by analysing how mining and migration intersect in the mobility trajectories of African men who work, or have worked, in gold mines and who have, or intend to extend their mobility to North Africa or Europe. In doing so, the article asks whether and how these men strategically articulate these two forms of mobility. By giving a voice to people who regularly cross-national borders, but who do not necessarily identify themselves as 'migrants,' the article provides a case that challenges some of the premises in the approach to migration decision-making.

The reason for this common approach to apparently separate 'flows' is twofold. First, the mining boom of the last decade has led to an increase in informal artisanal mining sites along the Birimian belt in Senegal, 
Mali, Guinea, Côte d'Ivoire and Burkina Faso, and more recently in the northern Sahel and Sahara in Mali and Niger, with the result that the routes of miners and migrants are likely to overlap. Secondly, there is little dialogue between the growing literature on artisanal mining and the literature on migration. Researchers in both fields tend to use their own categories of 'livelihoods' and 'migration' to refer to people on the move as either 'miners' or 'migrants,' whereas the lived experience of these men may relate to one or the other of these categories at different points in their trajectories. Furthermore, with the increasing criminalization of cross-border movements due to the externalization of European borders into Africa (Andersson, 2014; Brachet, 2018), the current context inevitably raises highly political questions such as whether artisanal mining has become a common source of funding for 'irregular' international migration routes out of Africa (e.g., Yonlihinza, 2017). To avoid ambiguity, let me state at the outset that the answer developed in this article is no. However, the actual overlaps between mining and migration routes and the fact that 'miners' can sometimes be 'migrants' and 'migrants' can sometimes be 'miners' nevertheless deserves sustained attention. In particular, because their trajectories call into question certain assumptions in the literature on the decision to migrate, such as the identification of different stages in the ambition and capacities to migrate (Carling \& Schewel, 2018; Haas, 2011).

From this point of view, a brief methodological note is important. The mobility profiles on which this study is based do not quantitatively represent a large share of male 'miners' or 'migrants.' However, they illustrate qualitatively how different types of mobility intersect along the mobility trajectories of West African men, something that the migration approach to 'decision-making' can hardly capture. As their narratives show, the elusive identification of a decision to migrate can, in their case, obscure the processual adjustments in men's search for livelihoods and social recognition, for which mobility is used within and outside West Africa. A second noteworthy point is the gendered aspect of the trajectories scrutinized in this article. Neither migration nor mining mobility are male prerogatives. As Hertrich and Lesclingand (2013) recall, labour mobility for the youth is equally important among young Malian women as it is for men, yet they partake in different expectations and projects. While male mobility is part of households' economics and strengthens their family status, as will be shown in the next section, female mobility is rather seen as a personal project geared towards acquiring life skills more prone to be obtained in cities than in gold mines (e.g. learning the national language or acquiring domestic 'know how'). Yet, women represent $40 \%$ to $50 \%$ of the workforce in informal gold mines (Huggins, Buss, \& Rutherford, 2017). In terms of mobility however, women are more likely to be from neighbouring villages from where they commute, and thus conciliate domestic labour with generating cash incomes by work- ing as panners or petty traders in the mines. Though women, like men, seek financial autonomy (Brottem \& $\mathrm{Ba}, 2019$; Werthmann, 2009) by undertaking short-term circular moves to the gold mines, they are less likely, as Dessertine argues (2013), to continue such a mobile lifestyle on the long run. The trajectories examined in this article-ranging from 3 to 10 years of travels-are, from this perspective, typically male gendered. Taking the lens of these 'mobility trajectories' (Schapendonk, van Liempt, Schwarz, \& Steel, 2018), the article argues that these African men, who, paraphrasing Hui (2016), are 'sometimes migrants' and 'sometimes miners,' primarily seek to increase their mobility, which in turn, is increasingly hampered by the expansion of European migration control and repressive policies on the continent.

In making this argument, I draw on field research conducted in 2020 in Mali and Guinea, telephone interviews with male miners/migrants in North Africa and Europe, as well as on data from a series of surveys on migration to artisanal mining sites in West Africa conducted by IOM as part of the broader programme "Protection and Assistance to Vulnerable Migrants in West and Central Africa." The article begins with a discussion on the notion of mobility trajectories (Schapendonk et al., 2018) in relation to the migration decision-making framework, and highlights its relevance in capturing the multiple constellations of movements that are characteristic of West Africa's mobile 'normality.' Next, I draw on IOM data to sketch the main patterns of mobility in the informal gold mining sector in order to identify where mining and migration routes overlap. Finally, I use in-depth interviews with seven miners/migrants to propose two main relationships between mining and migration routes, which I call 'mobility expansion' and 'refuge relationship.'

\section{Mobility and Migration in Mineralised West Africa}

Although there is a recent trend to overcome certain epistemological separations through the use of reflexivity (Dahinden, 2016) and mobility-based approaches (e.g., Moret, 2018; Schapendonk, 2020; Schapendonk, Bolay, \& Dahinden, 2020), studies on mobility and migration in and from Africa often demonstrate an epistemological ambiguity inherent in the decoupling of approaches by researchers rooted either in livelihoods and development research or in migration research. It is, for example, revealing that cross-border movements within the region tend to be labelled as mobile livelihoods and labour mobility (e.g., d'Errico \& Di Giuseppe, 2018), while cross-border movements across the Sahara and beyond tend to be labelled as international migration (Adepoju, 2006). In fact, both often meet similar criteria in terms of border crossing and time spent in another country, except that they face different 'mobility regimes' (Glick Schiller \& Salazar, 2013) and 'migration industries' (Andersson, 2014; Cranston, Schapendonk, \& Spaan, 2018). 
Yet these two approaches share the predominance of the economic prism to explain why people move, at the expense of other factors, and therefore fail to explain why people engage in mobility projects whose outcomes are at best uncertain and at worst deadly (Smith, 2019). Why move to an artisanal mining site knowing that the chances of becoming rich are so small compared to the risks of being injured, getting sick or dying in a collapsed shaft? Why move across the Sahara and possibly the Mediterranean knowing that the risks are so high? Without downplaying economic factors, the anthropological record provides a relatively solid body of knowledge about culturally embedded mobility practices in West Africa that can help broaden the understanding of how decisions to move are made.

Without going into all the ethnological details for reasons of conciseness, it is nonetheless useful to recall the importance of social recognition, or the continuing struggle to "produce personhood" (Comaroff \& Comaroff, 2001, p. 273) and "avoid social death" (Comaroff \& Comaroff, 2001, p. 274) in a wide range of African contexts. In the Mandé region, where most of my informants come from, social identities are strongly marked by norms of gender and seniority, with contradictory injunctions well encapsulated in the twin concepts of fadenya and badenya (Bird \& Kendall, 1980; the Mandé region here refers to the Mandé speaking area including Malinké, Bambara, Dioula, Mandinka, and Soninké language groups spread across Guinea, Mali, Norther Côte d'Ivoire, the Gambia, and the South and East of Senegal; for more on the sociocultural organisation and political history of this designation see Amselle, 1990; Conrad \& Frank, 1995). Drawing on the figure of the Mandé hero, they replicate the typical relations between classificatory brothers born to different mothers and are used in everyday talk to qualify and attribute different values to behaviours and actions. The fadenya, because of the competition between collateral brothers, "is associated to centrifugal forces of disequilibrium: envy, jealousy, competition, self-promotion-anything tending to spin the actor out of his established social force field" (Bird \& Kendall, 1980, p. 15). In contrast, the "badenya is associated with centripetal forces of society: submission to authority, stability, cooperation, those qualities which pull the individual back into the social mass" (Bird \& Kendall, 1980, p. 15), that is, obedience to norms. The fadenya and badenya can therefore be described as the two sides of masculinity, each enacting apparently contradictive moral principles and temporalities of action. Young men are thus expected to empower themselves and become adults by engaging in adventurous endeavours (Bredeloup, 2008), while at the same time contributing socially and economically to the perpetuation of the home village and the household through their presence. The home village, where lineage genealogies are enacted and reproduced, and where social personality is ultimately granted, embodies ideals of permanence, which are realised through physical presence, visits, remittances and, more generally, the maintenance of social ties (Dessertine, in press; Gaibazzi, 2015; Whitehouse, 2012). These antagonistic expectations have long been resolved by the circular mobility of labour within and outside Africa (Amselle, 1976; Manchuelle, 1997; Meillassoux, 1975).

But in a context of deagrarianisation, mass unemployment, conflict-related violence and the increasing criminalization of displacement, these age-prescribed journeys are increasingly difficult to achieve. As a result of this condition of 'involuntary immobility' (Jónsson, 2011), young men are likely to engage in relatively indeterminate forms of 'social navigation' (Vigh, 2009) that involve making and maintaining movements in uncertain settings. This is manifested not only in the turbulent trajectories' of irregular migration to Europe (Schapendonk, 2012), but also in growing mobilization in war economies (Hoffman, 2011), the performance of migration in immobility (Fioratta, 2015), or mobility within artisanal gold mines across the continent (Bredeloup, 1994; Dessertine, 2016), which may in turn hamper hopes for connectedness among those who stayed (Gaibazzi, 2019). From the point of view of the trajectory of African men on the move, these different forms of mobility are likely to intermingle and overlap with one another without following a precise roadmap. Consequently, these routes can hardly be captured through concepts such as the 'migratory journey' with supposedly well-separated phases of preparation, travel, transit, arrival and settlement (see Schapendonk et al., 2020). The approach to the mobility trajectories adopted in this article is therefore better suited, as it leaves more room for notions such as incoherence (Massa, 2018) or chance (Gladkova \& Mazzucato, 2017), to show that cross-border mobility within and outside Africa does not necessarily result from a migration project, nor is it necessarily conceived as 'migration' by those undertaking those cross-border movements.

In what follows, I begin by sketching how mining and migration mobility overlap based on IOM data on mobility flows in West African gold mines; I will also use data from Flow Monitoring Points at two sites where mining and migration routes to North Africa/Europe intersect.

\section{Overlapping Migration and Mining Routes}

The continued expansion of artisanal mining in West Africa (Hilson \& Garforth, 2012) has recently taken a turn with a new series of gold rushes in the Sahel and Sahara (Chevrillon-Guibert, Gagnol, \& Magrin, 2019). While traditional mining areas were mainly concentrated along the Birimian belt in the southern Sahel and tended to overlap with rural areas of 'migration departure' as formulated by the IOM, these new mining areas overlap with what migration research calls 'transit places' along the central Mediterranean route, such as Kidal in Mali or Agadez in Niger.

A quick comparison of two recent maps illustrates this point. As can be seen below (Figure 1), the largest 


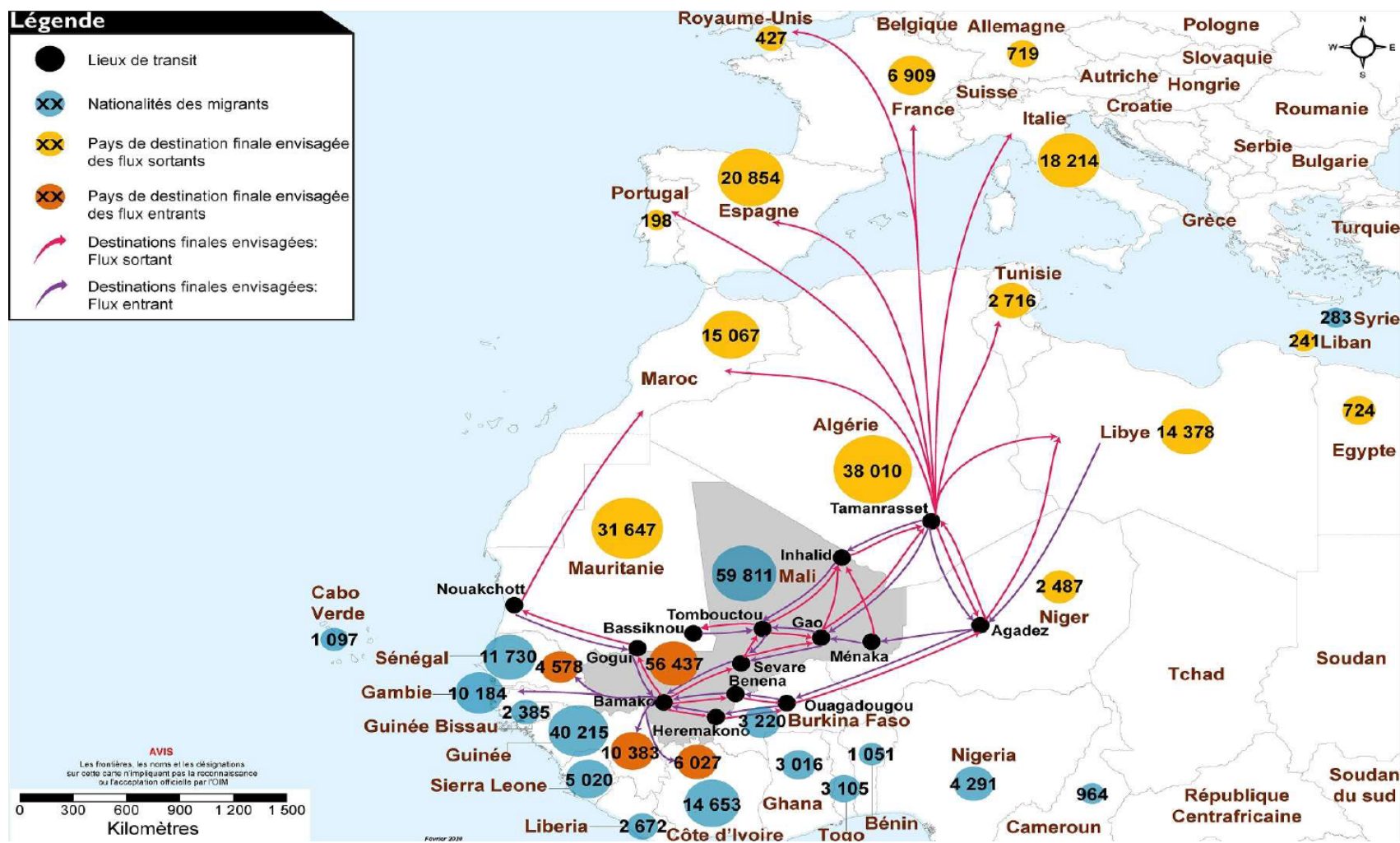

Figure 1. Map of migration routes. Notes: The designations employed and the presentation of material on the map reproduced in this article do not imply the expression of any opinion whatsoever on the part of the IOM; all data are based on estimates. Source: IOM (2020).

flows recorded at the Flow Monitoring Points of the IOM Displacement Tracking Matrix pass through Mali and Niger, whose northern areas are also the scene of some of the current major Saharan-Sahelian gold rushes (Figure 2 ) and where some 'transit' sites such as Inhalid or Agadez are located next to intense artisanal mining operations. In addition, the countries with the largest number of potential migrants (Mali, Guinea, Côte d'Ivoire and Senegal) are also countries where artisanal mining is a major activity, with an estimated 500,000 miners in Mali, 250,000 in Guinea, 500,000 in Côte d'Ivoire and between 50,000 and 100,000 in eastern Senegal (Alliance for Responsible Mining, 2020).

\subsection{Overlapping Routes in the Southern Sahel}

Mobility in informal artisanal mining occurs in different patterns. Mining is most often undertaken as a complementary activity to agriculture, with alternating dry and rainy seasons (Cartier \& Bürge, 2011). In such configurations, most miners are locals or come temporarily from other locations before returning to agriculture. However, for some miners, gold mining turned into their main activity. For example, out of the 54 respondents with whom I conducted network interviews on their mobility, $83 \%$ had kept mining as their main activity for more than four years and $63 \%$ had moved outside their country of residence to mine gold. This second configuration, on which this article focuses, involves continu- ous transitions and temporary settlements between successive mines, depending on opportunities (Bryceson, Bosse Jønsson, \& Clarke Shand, 2020) and evictions from workplaces due to illegal operations (Bolay, 2014, 2016a; Dessertine, 2019).

Recent studies conducted by IOM on gold mining sites in Senegal $(n=221)$, Guinea $(n=705)$ and Mali $(n=436)$ are useful in assessing miners' types of mobility and contextualizing them for possible future migration. All three studies highlight the important mix of nationalities in the sub-region, with almost half of the miners' population coming from neighbouring countries (Guinea: 42\%; Senegal: 72\%; Mali: 52\%), underlining the intensity of movements between mining sites spread across national borders. Moreover, while miners, who are on average under 30 years old at all sites, stayed for periods ranging from two weeks to three months in Guinea and up to a year in Senegal, they generally had no longer-term prospects. The Malian study, which is more detailed, also indicates a high turnover rate between mining sites, with $64 \%$ of the miners having visited and worked in more than two mines successively. In another manifestation of what could be called the transnational space of artisanal mining, the vast majority of prospective miners had obtained information prior to their visit from other artisanal miners. It is also interesting to note that $21 \%$ of respondents in Mali had initially obtained information from migration brokers, suggesting that some of them may have first entered the mines 


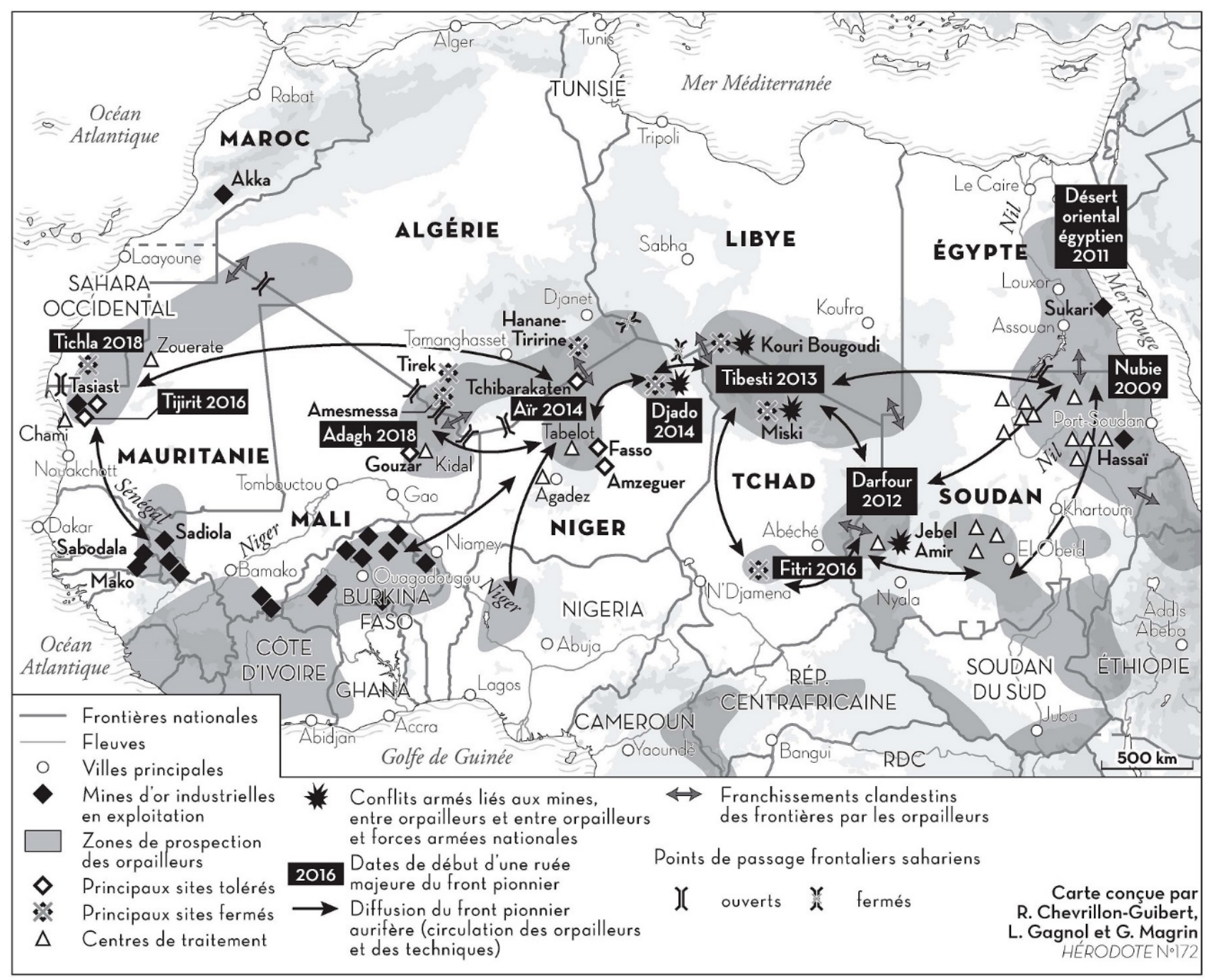

Figure 2. The artisanal front of the gold pioneers in the Saharo-Sahelian space. Note: Reproduced with authors' permission. Source: Chevrillon-Guibert et al. (2019, p. 196).

to collect money to fund an extra-continental migration project later on. Finally, in terms of their prospects for future travel, while most respondents planned to return home or to continue mining in the region, $9 \%$ in Guinea and $7 \%$ in Mali did mention Europe as another possible destination, but only $1 \%$ clearly saw mining as a step in a migration project. In an interview (20 February 2020, Bamako), IOM researchers also added that the vast majority of respondents who were not seasonal farmerminers did not know what their next destination would be. Thus, although prospective miners may have general medium-term objectives (to return home with capital, to pursue mining routes, or less frequently to cross the Sahara at a later stage), the precise steps to reach them are largely undetermined and subject to the opportunities they may encounter along the way.

To summarise the main conclusions of the IOM studies, artisanal gold mines in the southern areas appear as a circulatory space (Tarrius, 1993) made up of everchanging destinations spread across national borders. This space supports the mobile livelihoods of young men who are under economic pressure and who have very few other means to follow cultural scripts of constructing adulthood.

\subsection{Overlapping Routes in the Northern Sahel}

While IOM has conducted research in the 'traditional' artisanal mining areas - the southern areas in Figure 2what the research does not address is the current Saharan-Sahelian gold rush (Chevrillon-Guibert et al., 2019), which has led to the emergence of a number of new informal gold mines in northern Mali and Niger (see Figure 2). Due to the political instability in the region and the presence of several extremist groups, information is still extremely scarce. Recent research in Mali (Bolay, in press a) indicates that, in contrast to the 'traditional' areas in the south, workers tend to come mainly from Niger, Chad and Sudan-where this new 'pioneer front' originated (Chevrillon-Guibert et al., 2019). Similarly, in the Nigerian sites in the Aïr and Ténéré regions, reached from Agadez, Grégoire and Gagnol (2017) also observed 
that workers came mainly from these same countries, including many 'repatriates' from Libya. However, with the increasing discharge of the repression of overseas migration to Algerian and Libyan authorities (Brachet, 2018), a growing number of sub-Saharan Africans have been expelled from Algeria and Libya to the Nigerian and Malian borders. For example, in August 2019, the IOM registered 417 persons returned to the Nigerian borders by Algerian authorities. This trend was reinforced by the stricter enforcement of borders' closure due to the Covid-19 pandemic, which led to the confinement of deported populations in IOM camps (Afane, 2020), from which many have escaped. In the absence of economic relief opportunities, the current situation also raises the question of whether the deportees might not end up looking for livelihoods in the nearby mines (Afane, 2020). Although there is currently not enough information to support this hypothesis, research in the region of Kidal (Mali) and Agadez (Niger), which are both central nodes for migration routes and departure points to artisanal gold mines, suggests that the local migration industry has already begun to adapt to this overlap of mines and migration routes. For example, transporters in Kidal (Bolay, in press a) and in Agadez (Pellerin, 2017) have started to serve the routes to the Saharan artisanal mines, in addition to their usual transport of goods and irregular migrants across the borders.

While IOM surveys provide a useful quantitative 'snapshot' to identify points of overlap between mining and migration routes, they give no indication of how these different forms of mobility intersect along people's trajectories, nor how individuals move from one activity and destination to another. The following section addresses these issues qualitatively on the basis of indepth interviews with men whose trajectories involved both mobility in the gold mines and across the Sahara (and possibly beyond).

\section{Disentangling Mining and Migratory Mobility}

This section is based on seven in-depth interviews with men, all under the age of thirty when they first left their rural homes. These men represent relatively well the very diverse mix of nationalities present in artisanal mining in West Africa, with three of them from Guinea, two from Mali, one from Niger and one from Nigeria. They also represent one specific type of engagement in mining, which could be coined after Hilson and Garforth (2012, p. 353) as "full-time miners" whose mobility is not dictated by agricultural cycles. My aim here is to disentangle the mining and migratory mobilities along the trajectory of these itinerant miners in order to understand them in relation to each other. To do this, I pay particular attention to the general objectives and reasons given by the miners/migrants for leaving their home place as well as the way they adapted along the way, to the temporality of successive phases and forms of mobility (and immobility), and to the role of these different places (mines and places of 'transit') in shaping their future movements.

To reach out to men who combined or had combined mining and migration mobilities in their trajectory, I contacted informants I knew from previous research who themselves had such a profile, or who could put me in contact with others. I took the opportunity of a short field research trip in Mali in January and February 2020 to meet two of them in person-Kader was temporarily in Bamako before returning to the mining area of Kenieba, and Bo had stopped traveling and was now settled in Bamako. The other interviews were conducted by phone and WhatsApp during the same research stay, often in several shots because of connection losses or cuts due to empty credit. While these conditions somehow complicated the flow of the discussion, they nevertheless allowed for an exchange with people who were either in another country at this time or in remote locations in Mali. These trajectory interviews consisted in retracing the travels of the informants from their first departure to elicit the reasons that motivated their transitions from one place to another. For the analysis below, I selected those turning points where migrants became miners or miners became migrants and paid attention to the reasons that they gave for undertaking a new phase of mobility. In addition, I also took into consideration the temporal ordering of mobilities framed as mining and as migration, as well as their role in relation to the other along broader patterns of movement in the region. This framework made clear the theme of escape as a fruitful transversal descriptor to explain the relation between phases of immobility and mobility, both in mining and migratory contexts. It also helped define the relation between mining and migration either as an expansion of mobility, or as a refuge determined by the confrontation to Europe's intra African borders. For detailed information see Table 1.

\subsection{Departures: Aspirations and Capacities to Move, Not to Migrate}

All the stories collected share a similar starting point, namely the context of widespread poverty and lack of opportunities that characterised the respondents' lives when they left their place of residence in rural areas. To contextualize these stories, age is an important index, as all but one of the respondents were unmarried and did not have children at that time. Their status as young adults helps to explain why 'poverty,' a condition to which they all refer, is not expressed in terms of material deprivation, but rather in what could be described after Sen (1993) as a 'lack of ability' to carry out the projects expected at their age, such as being recognised for their social and economic contribution to the well-being of the lu (large household) or starting a family. As other researchers have shown, social and geographical immobility is indeed often perceived as two sides of the same coin among youths (Gaibazzi, 2015). 'Involuntary 
Table 1. Informants selected for in-depth trajectory interviews (the names used are pseudonyms).

\begin{tabular}{llcclll}
\hline Informant & Years & $\begin{array}{l}\text { Overseas migration } \\
\text { as a project at the } \\
\text { time of departure }\end{array}$ & $\begin{array}{l}\text { Temporal relation } \\
\text { mining to migration } \\
\text { labels }\end{array}$ & $\begin{array}{l}\text { Location at } \\
\text { the moment of } \\
\text { the interview }\end{array}$ & $\begin{array}{l}\text { Medium of } \\
\text { the interview }\end{array}$ \\
\hline Ali & Guinea & 6 & no & mining, migration, mining & Guinea & Phone \\
James & Guinea & 8 & no & mining, migration, mining & Mali & Phone \\
Bo & Mali & 10 & no & mining, migration, home & Mali & In person \\
Ibrahim & Guinea & 3 & no & mining, migration & Italy & Phone \\
Moussa & Mali & 6 & no & mining, migration, mining & Senegal & Phone \\
Kader & Niger & 5 & yes & migration, mining & Mali & In person \\
Felix & Nigeria & 11 & yes & migration, mining & Guinea & Phone \\
\hline
\end{tabular}

immobility,' as Jónsson (2011) has put it, can lead to a sense of 'uselessness' (Fioratta, 2015) that young men seek to escape by various means. One of the most accessible options in this region being the mines, it is a frequent first destination.

For example, James explains how he "remained seated most of the time, sometimes doing small jobs for the family" when, according to him, "in reality [he] had nothing to do." Similarly, Ali expresses that he was simply "discouraged by the lack of opportunities" and that "instead of waiting, [he] preferred to go and find money on his own." In this context, mobility rather than a specific migration project, is often a goal in itself. Following Carling and Schewel's (2018) distinction between aspirations and capacities to migrate, one could say that my informants had the aspiration to move (socially and geographically) and not the capacities to migrate, in particular to Europe. In a way, they manifest Carling and Schewel's (2018) argument in the other direction: Not having the capacities to migrate, most of them did not initially develop the aspiration to do so either, preferring to engage in 'adventurous' travels across the continent.

With regard to what my informants considered to be their point of departure, only Felix and Kader had designed their trips to resettle in another country, in their case a European country. All the others had seen travelling as a way of looking for money and seeing different places, with the firm intention of returning to their home place afterwards. Although this ideal pattern is rarely achieved, it nevertheless manifests what Dessertine (in press) calls the 'topocentric' conception of space that prevails in West African societies. Whereas Eurocentric sedentarist epistemologies define space by its limits materialised by borders (Molland, 2018), West African epistemologies define space by its core, in this context the place of dwelling or fabara in the Mande (literally the place of the father), and its expansion by mobility practices which do not question the centrality of the fabara. Mobility, including cross-border mobility, across the Sahara or the Mediterranean is, from this point of view, rarely conceived as migration, in the sense of resettlement towards the creation of a new core. However, the expansion of the mobility regime of Europe's borders in Africa is an empirical reality that contributes to the migranticisation (Dahinden, 2016) of people, routes and places, and thus shapes mobilities in Africa and beyond. The following section examines how the phases of mining and migratory mobilities intersect along the trajectories of miners/migrants.

\subsection{Intersecting Phases of Mobility along Miners/Migrants' Trajectories: Indebtedness, Escape and Refuge}

While most of my informants began their travels with age-related aspirations to earn money and social autonomy in order to progress along prescribed steps towards male adulthood, their travel experiences were rarely correlated with financial gain or greater freedom. On the contrary, they regularly found themselves captive, both socially and physically, in situations from which they tried to escape by resorting to new phases of mobility (for a discussion in the European context, see Schapendonk, 2020). Such situations echo Van der Velde and van Naerssen's (2011) argument that decisions to undertake (cross-border) travels are highly volatile and depend on specific situations along the trajectories (see also Crawley, Düvell, Jones, McMahon, \& Sigona, 2018). Below I briefly discuss three such typical situations in gold mines, migration routes, and border areas.

With regard to informal gold mining first, the social organization of work is strongly structured by what Panella has called 'worlds of debts' (2010), in which access to work, housing and gold itself is intertwined with supportive and dependent relationships based on the principles of friendship and patronage (Bolay, 2016b; Grätz, 2004). In their quest for financial autonomy and freedom of movement away from the fabara, young men who engage in mining work inevitably link themselves, to varying degrees, to such types of relationships which, if carefully managed, can enable them to support their mobile lifestyle, or otherwise can immobilize them against their will. Second, international migration is also often made possible by the mobilization of complex patterns of support. These relations of social and financial indebtedness blur the notions of "voluntary or autonomous choice" in migration decision-making (O'Connell Davidson, 2013, p. 177). While this has been 
well-documented at the presumed 'departure stage' (e.g., Konseiga, 2007), people on the move are in fact continuously engaged in 'network work' (Schapendonk et al., 2020) imbued with moralities of exchange and dependency to gain support along the way, thus contributing to shape their future movement possibilities. Finally, the European discharge of part of its migration control and repression apparatus to African states and international organisations (Andersson, 2014; Brachet, 2016) has been accompanied by an increase in legal and illegal practices of detention (cf. in Libyan prisons and IOM camps) and deportation (from Algeria or Libya to Niger) of 'irregular migrants.' These three modalities of movement conditioning, related to specific places, are regularly at stake along the trajectories of miners/migrants. As will be shown below, these modalities play contradictory roles, as they all have the power to trap individuals or to lead them to expand their movements by strategically engaging in new phases of mobility in order to escape.

Ali's story illustrates the first modality well. After managing to leave the harsh work of mining to become a small itinerant gold trader, Ali was robbed of a week's worth of work plus the financial advances from his sponsor, a trader based in Siguiri (Guinea). Feeling "disoriented" and knowing that he would not be able to repay his sponsor, Ali decided to leave not only the mines but also the country:

I decided to leave everything and continue the adventure. I had no idea about migration at first. But as I had to find money and couldn't stay [there], I decided to go and see in Libya. I wanted to work there, but it's difficult for us [sub-Saharan Africans] because we can't find good jobs. I did some painting for a while and it was good..... lot of people want to move [to Europe] there. I didn't plan that myself. But we were caught with other [sub-Saharan] Africans and brought to Niger anyway. (Ali, 17 February 2020, phone interview)

After some hesitation, he joined his family in Macenta (Guinea) where he obtained support to pay back his sponsor and resumed itinerant mining to pay back his family.

James' story shares very similar traits. Like Ali, after a few years of travelling to various gold mines, he suddenly decided to leave Guinea because of a family conflict over his own marriage. He travelled to Mali and Algeria to join a friend who was working in Morocco. Faced with difficulties entering Morocco, he stayed in Algeria for more than a year, working in construction, until one night the police arrested him and other sub-Saharan workers and expelled them 30 kilometres from the border with Niger. $\mathrm{He}$ and others were rescued by IOM buses which took them first to Arlit and then to Agadez. In order not to be forcibly sent back to Mali or Guinea, some of his travel companions escaped from the camp, allegedly to find work in the nearby mines and pay for passage back to
Algeria or Libya. As he himself was "too tired," he took the IOM transport to Bamako, and from there returned to the mines in Kenieba (Mali) in order not to return home to Guinea where his dispute was still unresolved.

While these two men inadvertently encountered the repressive migration regime during their mobility trajectories and then found refuge in the mines, Felix's trajectory highlights a reverse enterprise. Felix left Nigeria with the clear intention of passing through Libya to Europe. After a failed attempt to reach Italy, Felix was briefly imprisoned in Libya where he suffered daily police violence. When he was released, Felix was too scared to attempt a new passage and thought only of leaving Libya. In his case, it was the harsh encounter with Europe's intra-African borders and the discomfort of "going home with nothing," which would mean not repaying the moral debt of his absence, that led him to continue his travels. First he went to Niger and then to Burkina Faso, Mali and Guinea where he spent most of his time working and travelling from mine to mine, which seemed to him to be the most accessible livelihood option away from home.

Finally, it is interesting to look at the story of Ibrahim, the only informant who actually crossed over to Europe and got to Italy. Paradoxically, Ibrahim states clearly from the outset that "[he] never decided to emigrate [but he] continued to travel and took advantage of the opportunities that presented themselves," until he found himself in Libya and later in Italy. Like Ali and James, Ibrahim had already travelled through several countries (Ivory Coast, Mali, Liberia, Guinea), spending most of his time working in gold mines, and occasionally also in diamond mines. He decided to extend his mobility to Tunisia after realizing that "mining is too hard work if you don't have a good position yourself. You'll always have something at the end of the day, but it's never enough to move you forward." So, he planned to join a friend of his who had been living in Tunisia for several years, with the idea of building up capital and later investing it in mining operations. A few weeks after Ibrahim got to Tunisia, his friend left for Libya with the aim of moving to Italy, but without success. When Ibrahim learnt that his friend had been imprisoned before returning to Guinea "with almost nothing," Ibrahim curiously decided to "try his luck." As he says, "I hadn't really imagined being so close to Europe. I thought that, even if I hadn't worked towards this aim, since I was there and that my friend had left, I could try it too." When we spoke, Ibrahim was detained in Italy and waiting for his asylum application to be processed. However, he had already decided that it was not worth waiting for the outcome of the procedure and was already planning to travel to Spain as soon as he had the chance, as one of his friends had assured him that he would help him find work there.

The four vignettes presented above have in common that the trajectories of their protagonists successively cross mining and migration routes. Their travel decisions are less concerned with specific destinations than with contingencies linked to the contexts in which they are 
taken, and which young men often seek to escape by further expanding their mobility. When they travel to places labelled as migration routes, they inevitably face the violence that Europe's externalised borders exert on travellers from sub-Saharan Africa, regardless of whether they want to migrate to Europe or not. Gold mines play a more ambivalent role in their trajectories. On the one hand, the transnational circulation of territories that gold mines constitute socialises young men to cross borders in precarious conditions, which can sometimes drive them to continue their journeys further when they had not originally planned to. On the other hand, with virtually non-existent barriers to entry and a geography that intersects with migration routes, gold mines-despite the prevailing harsh working conditions-also seem to act as spaces of refuge for men who are forcibly expelled at Europe's externalized borders.

\section{Conclusion}

This article began with the observation that mining and migration routes are increasingly overlapping in Africa, raising the question of whether mining has become a common step towards migration out of the continent. By examining how mining and migration routes intersect along the trajectories of young West Africans on the move, the article confirmed IOM's findings that miners rarely engage in mining with a migration project in mind. However, by examining the mobility trajectories of some of these men who were sometimes considered migrants and sometimes miners, the article identified in more detail how these different routes relate to each other. While overseas migration is certainly not a common project for itinerant miners, the gold mines constitute a transnational space that favours the expansion of movements across the continent, including outside the field of mining. Rather than encouraging overseas migration, gold mining seems to be more of a safety net, not only for seasonal farmers or young people in search of money and adventure, but also, increasingly, for people who are confronted with Europe's intra-African borders. From this perspective, while suspicions that gold mining would be a stepping stone to overseas migration seem largely unfounded, the fact that travellersexpelled or deported from areas designated as migration routes-often have little choice but to seek refuge and economic relief in artisanal mines, calls for greater attention to the effects of the increasing criminalisation of travels (Brachet, 2018). Artisanal mining has now become the second largest source of livelihoods on the continent (Hilson, 2016), largely due to the lack of opportunities in other sectors which were historically structured by seasonal migration. The repression imposed by Europe's expanding mobility regime, therefore, not only restricts these options, but through its externalized borders also actively produces a heterogenized reserve of labour (Mezzadra \& Neilson, 2013) and indirectly feeds the informal artisanal mining sector with a low-skilled, cheap and unprotected workforce. Cynically enough, the product of their labour (gold) finds its way into licit markets through complex global supply chains that cross cut the realm of the formal and the informal, the licit and the illicit (Bolay, in press b; Verbrugge \& Geenen, 2020), and, as has been well demonstrated (Pieth, 2019), allows intermediaries and end producers partly based in Europe to make significant profits.

\section{Acknowledgments}

This research was funded by the Swiss Subsaharan Africa Migration Network (S-SAM; project Artisanal Miners) and supported by SNF (Project No. 173354). The author warmly thanks Didier Ruedin who coordinated the Network and the thematic issue, as well as the two anonymous reviewers for their generous comments. I am grateful to Sandaly Kourouma, and the IOM office in Bamako for their help.

\section{Conflict of Interests}

The author declares no conflict of interests.

\section{References}

Adepoju, A. (2006). Internal and international migration within Africa. In P. Kok, J. Oucho, D. Gelderblom, \& J. Van Zyl (Eds.), Migration in South and Southern Africa: Dynamics and determinants (pp. 26-46). Cape Town: Hsrc Press.

Afane, A. K. (2020, April 20). Niger: Impact of COVID-19 on gold mining sites. Delve. Retrieved from https://delvedatabase.org/news/impacts-of-covid19-on-artisanal-and-small-scale-mining-insightsfrom-the-ground

Alliance for Responsible Mining. (2020). Estimated number of artisanal and small-scale miners per country. Alliance for Responsible Mining. Retrieved from http://artisanalmining.org/Inventory

Amselle, J. L. (Ed.). (1976). Les migrations africaines: Réseaux et processus migratoires [African migrations: Networks and migration processes]. Paris: Maspero.

Amselle, J. L. (1990). Logiques métisses: Anthropologie de l'identité en Afrique et ailleurs [Mestizos logics: Anthropology of identity in Africa and Beyond]. Paris: Payot.

Andersson, R. (2014). Illegality, Inc.: Clandestine migration and the business of bordering Europe. Berkeley, CA: University of California Press.

Bilger, V., \& Kraler, A. (2005). African migrations: Historical perspectives and contemporary dynamics. Stichproben: Vienna Journal of African Studies, 5(8), 5-21.

Bird, C. S., \& Kendall, M. B. (1980). The Mande hero: Text and context. In I. Karp \& C. S. Bird (Eds.), Explorations in African systems of thought (pp. 13-26). Bloomington, IN: Indiana University Press.

Bolay, M. (2014). When miners become "foreigners": 
Competing categorizations within gold mining spaces in Guinea. Resources Policy, 41(3), 117-127.

Bolay, M. (2016a). Artisanal gold miners encountering large-scale mining in Guinea: Expulsion, tolerance and interference. In T. Niederberger, T. Haller, H. Gambon, M. Kobi, \& I. Wenk (Eds.), The open cut: Mining, transnational corporations and local populations (pp. 187-204). Zurich and Berlin: LIT Verlag.

Bolay, M. (2016b). “Il faut être là où l'or sort!” De l'itinérance temporaire au maintien d'un mode de vie mobile chez les orpailleurs de Haute Guinée [From temporary itinerancies to full time mobile livelihoods among artisanal miners in Upper Guinea]. Stichproben: Vienna Journal of African Studies, 30(1), 111-135.

Bolay, M. (in press a). Des réseaux aux chaînes d'approvisionnement: Économies morales et performances de moralisation dans le commerce de l'or au Mali post 2012 [From networks to supply chains: Moral economies and morality performance in Mali's gold trade post-2012]. Politique Africaine.

Bolay, M. (in press b). Fabricating the integrity of gold in refineries: Digital visibility and divisibility. TsantsaJournal of the Swiss Anthropological Association.

Brachet, J. (2016). Policing the desert: The IOM in Libya beyond war and peace. Antipode, 48(2), 272-292.

Brachet, J. (2018). Manufacturing smugglers: From irregular to clandestine mobility in the Sahara. The ANNALS of the American Academy of Political and Social Science, 676(1), 16-35.

Bredeloup, S. (1994). L'aventure contemporaine des diamantaires sénégalais [The contemporary adventure of Senegalese diamond dealers]. Politique Africaine, 56, 77-93.

Bredeloup, S. (2008). L'aventurier, une figure de la migration africaine [The adventurer, a figure of African migration]. Cahiers Internationaux de Sociologie, 2, 281-306.

Brottem, L. V., \& Ba, L. (2019). Gendered livelihoods and land tenure: The case of artisanal gold miners in Mali, West Africa. Geoforum, 105, 54-62.

Bryceson, D. F., Bosse Jønsson, J., \& Clarke Shand, M. (2020). Mining mobility and settlement during an East African gold boom: Seeking fortune and accommodating fate. Mobilities, 15(3), 446-463.

Carling, J., \& Schewel, K. (2018). Revisiting aspiration and ability in international migration. Journal of Ethnic and Migration Studies, 44(6), 945-963.

Cartier, L. E., \& Bürge, M. (2011). Agriculture and artisanal gold mining in Sierra Leone: Alternatives or complements? Journal of International Development, 23(8), 1080-1099.

Chevrillon-Guibert, R., Gagnol, L., \& Magrin, G. (2019). Les ruées vers l'or au Sahara et au nord du Sahel: Ferment de crise ou stabilisateur? [Gold rushes in the Sahara and Northern Sahel: A ground for crisis or stability?]. Hérodote, 1, 193-215.

Comaroff, J. L., \& Comaroff, J. (2001). On personhood: An anthropological perspective from Africa. Social Identities, 7(2), 267-283.

Conrad, D. C., \& Frank, B. E. (Eds.). (1995). Status and identity in West Africa: Nyamakalaw of Mande. Bloomington, IN: Indiana University Press.

Cranston, S., Schapendonk, J., \& Spaan, E. (2018). New directions in exploring the migration industries: Introduction to special issue. Journal of Ethnic and Migration Studies, 44(4) 543-557.

Crawley, H., Düvell, F., Jones, K., McMahon, S., \& Sigona, N. (2018). Unravelling Europe's migration crisis: Journeys over land and sea. Bristol: Policy Press.

Dahinden, J. (2016). A plea for the 'de-migranticization' of research on migration and integration. Ethnic and Racial Studies, 39(13), 2207-2225.

De Bruijn, M., van Dijk, R. A., \& Foeken, D. (Eds.). (2001). Mobile Africa: Changing patterns of movement in Africa and beyond. Leiden: Brill.

d'Errico, M., \& Di Giuseppe, S. (2018). Resilience mobility in Uganda: A dynamic analysis. World Development, 104, 78-96.

Dessertine, A. (2013). Le lu ne meurt jamais: Mobilités des individus et pérennité de la résidence dans un village malinké de Guinée [The Lu never dies: Individuals' mobility and sustainability of residence in a Malinke village in Guinea]. Géocarrefour, 88(2), 131-138.

Dessertine, A. (2016). From pickaxes to metal detectors: Gold mining mobility and space in Upper Guinea, Guinea Conakry. The Extractive Industries and Society, 3(2), 435-441.

Dessertine, A. (2019). Une justice foncièrement autre? Pouvoir et foncier en contexte minier aurifère (Guinée) [And justice for all land? Power and land in the context of gold mining (Guinea)]. Revue Internationale des Études du Développement, 2, 141-164.

Dessertine, A. (in press). A quoi tient le village: Espaces et mobilités en pays malinké (Guinée) [What does a village stands for: Space and mobility in Malinke country (Guinea)]. Nanterre: Société d'Ethnologie.

Fioratta, S. (2015). Beyond remittance: Evading uselessness and seeking personhood in Fouta Djallon, Guinea. American Ethnologist, 42(2), 295-308.

Gaibazzi, P. (2015). Bush bound: Young men and rural permanence in migrant West Africa. Oxford: Berghahn Books.

Gaibazzi, P. (2019). Moving-with-others: Restoring viable relations in emigrant Gambia. Migration and Society, 2(1), 26-39.

Gladkova, N., \& Mazzucato, V. (2017). Theorising chance: Capturing the role of ad hoc social interactions in migrants' trajectories. Population, Space and Place, 23. https://doi.org/10.1002/psp.1988

Glick Schiller, N., \& Salazar, N. B. (2013). Regimes of mobility across the globe. Journal of Ethnic and Migration Studies, 39(2), 183-200.

Grätz, T. (2004). Gold trading networks and the creation of trust: A case study from northern Benin. Africa, 74(2), 146-172. 
Grégoire, E., \& Gagnol, L. (2017). Ruées vers l'or au Sahara: L'orpaillage dans le désert du Ténéré et le massif de l'Aïr (Niger) [Gold rushes in the Sahara: Artisanal mining in the Tenere desert and the Air mountains (Niger)]. EchoGéo. https://doi.org/10.4000/ echogeo.14933

Haas, H. d. (2011). The determinants of international migration: Conceptualizing policy, origin and destination effects (Working Paper No. 32). Oxford: International Migration Institute.

Hahn, H. P., \& Klute, G. (Eds.). (2007). Cultures of migration: African perspectives. Münster: LIT Verlag.

Hertrich, V., \& Lesclingand, M. (2013). Adolescent migration in rural Africa as a challenge to gender and intergenerational relationships: Evidence from Mali. The Annals of the American Academy of Political and Social Science, 648(1), 175-188.

Hilson, G., \& Garforth, C. (2012). 'Agricultural poverty' and the expansion of artisanal mining in Sub-Saharan Africa: Experiences from Southwest Mali and Southeast Ghana. Population Research and Policy Review, 31(3), 435-464.

Hilson, G. (2016). Artisanal and small-scale mining and agriculture: Exploring their links in rural sub-Saharan Africa. London: IIED.

Hoffman, D. (2011). Violence, just in time: War and work in contemporary West Africa. Cultural Anthropology, 26(1), 34-57.

Huggins, C., Buss, D., \& Rutherford, B. (2017). A 'cartography of concern': Place-making practices and gender in the artisanal mining sector in Africa. Geoforum, 83, 142-152.

Hui, A. (2016). The boundaries of interdisciplinary fields: Temporalities shaping the past and future of dialogue between migration and mobilities research. Mobilities, 11(1), 66-82.

International Organization for Migration. (2020). Matrice de Suivi des Déplacements (DTM): Points de suivi des flux de population, aperçu des résultats \#48 [Displacement Tracking Matrix (DTM): Flow Monitoring Report, snapshot \#48]. Le Grand-Saconnex: International Organization for Migration.

Jónsson, G. (2011). Non-migrant, sedentary, immobile, or 'left behind'? (Working Paper No. 39). Oxford: International Migration Institute.

Konseiga, A. (2007). Household migration decisions as survival strategy: The case of Burkina Faso. Journal of African Economies, 16(2), 198-233.

Manchuelle, F. (1997). Willing migrants: Soninke labor diasporas, 1848-1960. James Currey: James Currey Publishers.

Massa, A. (2018). Borders and boundaries as resources for mobility: Multiple regimes of mobility and incoherent trajectories on the Ethiopian-Eritrean border. Geoforum. https://doi.org/10.1016/j.geoforum. 2018.01.007

Meillassoux, C. (1975). Femmes, greniers et capitaux [Maidens, meal and money: Capitalism and the domestic community]. Paris: Maspero.

Mezzadra, S., \& Neilson, B. (2013). Border as method, or, the multiplication of labor. Durham, NC: Duke University Press.

Molland, S. (2018). Sedentary optics: Static antitrafficking and mobile victims. Current Anthropology, 59(2), 115-137.

Moret, J. (2018). European Somalis' post-migration movements: Mobility capital and the transnationalisation of resources. Cham: Springer Nature.

O'Connell Davidson, J. (2013). Troubling freedom: Migration, debt, and modern slavery. Migration Studies, 1(2), 176-195.

Panella, C. (Ed.). (2010). Worlds of debts: Interdisciplinary perspectives on gold mining in West Africa. Amsterdam: Rozenberg Publishers.

Pellerin, M. (2017). Beyond the 'wild West': The gold rush in Northern Niger. Geneva: Small Arms Survey.

Pieth, M. (2019). Gold laundering: The dirty secrets of the gold trade. Zurich: Salis Verlag.

Schapendonk, J. (2012). Turbulent trajectories: African migrants on their way to the European Union. Societies, 2(2), 27-41.

Schapendonk, J., Bolay, M., \& Dahinden, J. (2020). The conceptual limits of the 'migration journey': Deexceptionalising mobility in the context of West African trajectories. Journal of Ethnic and Migration Studies. https://doi.org/10.1080/1369183X.2020. 1804191

Schapendonk, J., van Liempt, I., Schwarz, I., \& Steel, G. (2018). Re-routing migration geographies: Migrants, trajectories and mobility regimes. Geoforum. https:// doi.org/10.1016/j.geoforum.2018.06.007

Schapendonk, J. (2020). Finding ways through Eurospace: West African movers re-viewing Europe from the inside. Oxford and New York, NY: Berghahn Books.

Sen, A. (1993). Capability and well-being. In A. Sen \& M. C. Nussbaum (Eds.), The quality of life (pp. 270-293). Oxford: Clarendon Press.

Smith, S. (2019). The scramble for Europe: Young Africa on its way to the old continent. London: Wiley.

Tarrius, A. (1993). Territoires circulatoires et espaces urbains: Différentiation des groupes migrants [Circulatory territories and urban spaces: Differentiation of migrant groups]. Les Annales de la Recherche Urbaine, 59(1), 51-60.

Van der Velde, M., \& van Naerssen, T. (2011). People, borders, trajectories: An approach to cross-border mobility and immobility in and to the European Union. Area, 43(2), 218-224.

Vigh, H. (2009). Motion squared: A second look the concept of social navigation. Anthropological Theory, 9(4), 419-438.

Werthmann, K. (2009). Working in a boom-town: Female perspectives on gold-mining in Burkina Faso. Resources Policy, 34(1/2), 18-23.

Whitehouse, B. (2012). Migrants and strangers in an African city: Exile, dignity, belonging. Bloomington, 
IN: Indiana University Press.

Yonlihinza, I. A. (2017, May 15). As more people flock to Niger's gold mines, economic boon may become a new migration risk. The Conversation. Retrieved from https://theconversation.com/as-more-peopleflock-to-nigers-gold-mines-economic-boon-maybecome-a-new-migration-risk-75417

\section{About the Author}

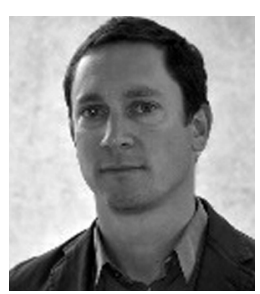

Matthieu Bolay is a Social Anthropologist and Postdoctoral Researcher at the Graduate Institute for International and Development Studies, Geneva (Switzerland). He has expertise in the politics of extraction and his research lies at the crossroads of migration, labour, politics and the law. 